\title{
Bacillus oryzicola sp. nov., an Endophytic Bacterium Isolated from the Roots of Rice with Antimicrobial, Plant Growth Promoting, and Systemic Resistance Inducing Activities in Rice
}

\author{
Eu Jin Chung ${ }^{1 \dagger}$, Mohammad Tofajjal Hossain ${ }^{1 \dagger}$, Ajmal Khan ${ }^{1}$, Kyung Hyun Kim ${ }^{2}$, Che Ok Jeon ${ }^{2}$ and \\ Young Ryun Chung ${ }^{1 *}$ \\ ${ }^{I}$ Division of Applied Life Science (BK21 Plus), Plant Molecular Biology and Biotechnology Research Center, Gyeongsang \\ National University, Jinju 660-701, Korea \\ ${ }^{2}$ Department of Life Science, Chung-Ang University, Seoul 156-756, Korea
}

(Received on December 29, 2014; Revised on April 6, 2015; Accepted on April 7, 2015)

Biological control of major rice diseases has been attempted in several rice-growing countries in Asia during the last few decades and its application using antagonistic bacteria has proved to be somewhat successful for controlling various fungal diseases in field trials. Two novel endophytic Bacillus species, designated strains YC7007 and $\mathrm{YC7010}^{\mathrm{T}}$, with antimicrobial, plant growth-promoting, and systemic resistance-inducing activities were isolated from the roots of rice in paddy fields at Jinju, Korea, and their multifunctional activities were analyzed. Strain YC7007 inhibited mycelial growth of major rice fungal pathogens strongly in vitro. Bacterial blight and panicle blight caused by Xanthomonas oryzae pv. oryzae (KACC 10208) and Burkholderia glumae (KACC 44022), respectively, were also suppressed effectively by drenching a bacterial suspension $\left(10^{7} \mathrm{cfu} / \mathrm{ml}\right)$ of strain YC7007 on the rhizosphere of rice. Additionally, strain YC7007 promoted the growth of rice seedlings with higher germination rates and more tillers than the untreated control. The taxonomic position of the strains was also investigated. Phylogenetic analyses based on 16S rRNA gene sequences indicated that both strains belong to the genus Bacillus, with high similarity to the closely related strains, Bacillus siamensis KACC $15859^{\mathrm{T}}$ (99.67\%), Bacillus methylotrophicus KACC $13105^{\mathrm{T}}$ (99.65\%), Bacillus amyloliquefaciens subsp. plantarum KACC $17177^{\mathrm{T}}(\mathbf{9 9 . 6 0 \%})$, and Bacillus tequilensis KACC $15944^{\mathrm{T}}(\mathbf{9 9 . 4 5 \% )})$. The DNA-DNA relatedness value between strain $\mathrm{YC7010}^{\mathrm{T}}$ and the most closely related

\footnotetext{
${ }^{\dagger}$ Contributed equally.

*Corresponding author.

Phone) +82-55-772-1326, FAX) +82-55-772-1329

E-mail)yrchung@gnu.ac.kr
}

strain, B. siamensis KACC $15859^{\mathrm{T}}$ was $50.4 \pm 3.5 \%$, but it was $91.5 \pm 11.0 \%$ between two strains YC7007 and $\mathrm{YC7010}^{\mathrm{T}}$, indicating the same species. The major fatty acids of two strains were anteiso- $C_{15: 0}$ and iso $C_{15: 0}$. Both strains contained MK-7 as a major respiratory quinone system. The $\mathbf{G}+\mathbf{C}$ contents of the genomic DNA of two strains were $50.5 \mathrm{~mol} \%$ and $51.2 \mathrm{~mol} \%$, respectively. Based on these polyphasic studies, the two strains YC7007 and YC7010 ${ }^{\mathrm{T}}$ represent novel species of the genus Bacillus, for which the name Bacillus oryzicola sp. nov. is proposed. The type strain is $\mathrm{YC7010}^{\mathrm{T}}$ (= KACC $\left.18228^{\mathrm{T}}\right)$. Taken together, our findings suggest that novel endophytic Bacillus strains can be used for the biological control of rice diseases.

Keywords : bacterial blight, endophytes, induced systemic resistance, leaf rot, novel Bacillus, rice growth promotion

Rice is the staple food over half of the world population and its production was estimated approximately 745 million tonnes in 2013 worldwide. Asia ranks highest in rice production but $24-41 \%$ of losses occur annually due to the major limiting factor, diseases (Anon., 2014; Savary et al., 2000). More than 70 diseases caused by fungi, bacteria, viruses, and nematodes have been recorded in rice and especially rice blast, bacterial leaf blight, grain rot, and bakanae are the most serious seed-borne diseases reducing yields (Ou, 1985). The bacterial blight caused by Xanthomonas oryzae pv. oryzae enormously affects yield losses $10-50 \%$ of total rice production, depending on the situation (Mew, 1992). Other bacterial diseases including seedling blight and rot, leaf sheath rot, leaf browning, panicle blight, bacterial wilt, and grain rot caused by Burkholderia glumae reduced the yield by up to $75 \%$ 
in some cases (Kim et al., 2010; Ura et al., 2006). The yield losses due to bakanae caused by Fusarium fujikuroi were estimated to be approximately $10-50 \%$ in the Asian rice-growing areas (Bonman, 1992). For controlling the diseases, chemical fungicides have been widely used in most Asian countries during past decades, but the efficacy of fungicides has decreased recently due to the occurrence of resistance (Yang et al., 2012). Additionally, the misuse of chemical fungicides has adverse effects on the agricultural environment and farmers, so the development of alternative control measures, specifically, biological controls using antagonistic microorganisms, has been attempted in many Asian countries (Gnanamanickam, 2009).

Biological control using antagonistic bacteria would be environmentally sound and can be implemented as an integrated disease management tool. Various bacterial genera, such as Bacillus, Burkholderia, Lysobacter, Pantoea, Pseudomonas, and Streptomyces have been used as biocontrol agents for controlling diseases of many crops, but a few studies have been reported on the biological control of rice diseases (Bouizgarne, 2013; McSpadden Gardener, 2010). The multiple use of antagonistic bacteria Streptomyces and Bacillus species has been attempted for the control of rice sheath blight (Sung and Chung, 1997). Rice blast and sheath blight were controlled effectively by Bacillus vallismortis EXTN-1 and two antagonistic bacterial strains, Pseudomonas fluorescens mc75 and pc78 (Choi et al., 2006; Park et al., 2006). Bakanae and seedling rot of rice caused by Fusarium moniliforme and $F$. fujikuroi were also controlled by antagonistic $P$. fluorescens and Bacillus cereus (Kazempour and Elahinia, 2007; Rosales and Mew, 1997). Among the diverse antagonistic bacteria, several Bacillus species have been developed as commercial bio-pesticides, because Bacillus species can produce endospores and persist successfully in natural environments for a long period after treatment $(\mathrm{Hu}$ et al., 2011).

Bacillus species widely used for biological control of many plant diseases in different hosts include Bacillus amyloliquefaciens, Bacillus subtilis, Bacillus pasteurii, B. cereus, Bacillus pumilus, Bacillus mycoides, and Bacillus sphaericus (Kloepper et al., 2004; McSpadeen Gardener, 2010). B. subtilis GB03 and B. amyloliquefaciens IN937 were demonstrated to control the bacterial pathogen, Erwinia carotovora subsp. carotovora in Arabidopsis (Ryu et al., 2004). B. cereus AR156 and B. subtilis were also demonstrated to control Pseudomonas syringae pv. tomato DC3000 successfully in Arabidopsis by inducing resistance (Niu et al., 2011). Some of these Bacillus species have been well characterized in terms of their anti-fungal, anti-bacterial, plant growth-promoting, and resistanceinducing activities in host plants (Park et al., 2009; Ryu, 2013). Diverse species of Bacillus have been isolated from various terrestrial and halophytic plants and some of them have been shown to be endophytic (Bibi et al., 2011, 2012). The genus Bacillus currently contains 299 species and more than 30 species have been reported to be novel during the last 5 years, based on polyphasic studies, including $16 \mathrm{~S}$ rRNA gene sequences, DNA-DNA hybridization analyses, fatty acid profiles, and physical and biochemical tests (Parte, 2014).

In this study, two Bacillus strains YC7007 and YC7010 isolated from the roots of rice were examined in developing a novel biocontrol agent with multifunctional activities and further characterized for identification by a polyphasic approach. The control efficacy of the novel strain YC7007 was also investigated through induction of resistance against bacterial blight and panicle blight as well as growth promotion in rice.

\section{Materials and Methods}

Isolation and cultivation of endophytic bacteria. Endophytic bacterial strains were isolated from the rice roots collected at the paddy field of Gyeongsang National University Farm, Jinju, Korea. For the isolation, sample pieces were washed several times with running tap water and surface-sterilized with $70 \%$ ethanol for $5 \mathrm{~min}, 1.2 \%$ $\mathrm{NaOCl}$ solution for $10 \mathrm{~min}$, and finally washed with sterile distilled water several times. To confirm the successful disinfection, washed segments were placed on one-tenth strength tryptic soy broth agar $(1 / 10 \mathrm{TSA})$ at $28^{\circ} \mathrm{C}$ for 3 days and bacterial growth was observed. After confirmation of no bacterial colonies, the sample segments were again sterilized by $70 \%$ ethanol for a few seconds and ground in autoclaved distilled water with a sterile mortar and pestle (Bibi et al., 2012). Aliquots were 10-fold serially diluted in autoclaved distilled water and the diluted samples were kept in a hot water bath $\left(80^{\circ} \mathrm{C}\right)$ for $10 \mathrm{~min}$ to select endospore-forming bacterial species. An aliquot $(0.1 \mathrm{ml})$ was plated on 1/10 TSA media supplemented with cycloheximide $(50 \mu \mathrm{g} / \mathrm{ml})$ and the plates were incubated at $30^{\circ} \mathrm{C}$ for 3 days. The bacterial colonies grown on the medium were selected on the basis of distinct colony morphology. The bacterial strains isolated purely were subcultured on $1 / 10$ TSA media and stored at $-70^{\circ} \mathrm{C}$ for further use. For cultivation of bacterial strains, medium containing $10 \mathrm{~g}$ protease peptone, $10 \mathrm{~g}$ yeast extract, $4 \mathrm{~g} \mathrm{NH}_{4} \mathrm{Cl}, 4 \mathrm{~g}$ $\mathrm{MgSO}_{4}, 10 \mathrm{~g}$ glucose, and $15 \mathrm{~g}$ agar per liter distilled water was prepared. 
Antagonistic activity against fungal and bacterial pathogens. The endophytic bacteria were tested against important plant fungal pathogens, such as Alternaria panax KACC 42461, F. fujikuroi KACC 44022, F. oxysporum KCTC 16909, Sclerotinia sclerotiorum GSCC 50501, Pythium ultimum GSCC 50651, Bipolaris oryzae KACC 40853, Botrytis cinerea KCTC 6973, Magnaporthe grisea KACC 40415, Botryosphaeria dothidea GSCC 50201, and Rhizoctonia solani KCTC 40101. The antagonistic activity of bacterial strains was determined by measuring the inhibition zone of mycelial growth of the fungal pathogens on potato dextrose agar (PDA) medium using in vitro confrontation bioassay (Bibi et al., 2012). For the antibacterial test, B. glumae KACC10359 and X. oryzae pv. oryzae KACC 10208 were grown on one-half strength R2A and YGC media (10 g glucose, $30 \mathrm{~g} \mathrm{CaCO}_{3}, 5$ g yeast extract, and $15 \mathrm{~g}$ agar per liter distilled water), respectively and the inhibition activity was tested using a diffusion paper disc method. Culture filtrate of the bacterial strain YC7007 was prepared from the culture broth with different cultivation times by centrifugation $(5,000 \mathrm{~g}, 10 \mathrm{~min})$ and filtration through a Millipore filter $(0.2 \mu \mathrm{m})$.

Bioassay of induced resistance against bacterial pathogens. Induction of resistance by strain YC7007 was tested against bacterial blight and panicle blight caused by X. oryzae pv. oryzae KACC 10208 and B. glumae KACC 10359, respectively, in pot tests. Seeds of rice (Oryza sativa L. cultivar Dongjin) were surface-sterilized with $1.2 \% \mathrm{NaOCl}$ solution for $5 \mathrm{~min}$ and $70 \%$ ethanol for 5 min, then rinsed three times with sterile distilled water. The seeds were then kept at $30^{\circ} \mathrm{C}$ for 3 days in the dark for germination and the water was changed every day. The germinated seeds were sown in commercial nursery soil (Dasuran Sangto, Youngnong Sun Up, Korea) and placed in a greenhouse for cultivation. Then, 2-week-old seedlings were transplanted into plastic pots $\left(9.5 \times 8 \times 7 \mathrm{~cm}^{3}\right)$ containing about $150 \mathrm{~g}$ commercial nursery soils that had been autoclaved for $20 \mathrm{~min}$ at $121^{\circ} \mathrm{C}$ twice on two consecutive days. For the preparation of a bacterial suspension of YC7007, bacterial cells were cultivated for two days in the liquid mass culture medium on a rotary shaker $(160 \mathrm{rpm}$, $\left.28^{\circ} \mathrm{C}\right)$ and harvested by centrifugation $(5,000 \mathrm{~g}, 10 \mathrm{~min})$ and adjusted to different concentrations $\left(5.6 \times 10^{5}, 3.6 \times 10^{6}\right.$, $\left.2 \times 10^{7} \mathrm{cfu} / \mathrm{ml}\right)$ in buffer solution $\left(10 \mathrm{mM} \mathrm{MgSO}_{4}\right)$. The cell suspension $(15 \mathrm{ml})$ of YC7007 was drenched into the plastic pot containing autoclaved soils (150 g) during transplanting 2-week-old rice seedlings at the same time. The optimal concentration of YC7007 $\left(2 \times 10^{7} \mathrm{cfu} / \mathrm{ml}\right)$ was used for testing further resistance induction against bacterial blight and panicle blight. The culture filtrate of strain YC7007 prepared from a $60 \mathrm{~h}$ culture broth that was diluted 10 times with the $10 \mathrm{mM} \mathrm{MgSO}$ and sprayed to the leaves until to droplet for checking its control efficacy. Then, five days after treatment with YC7007, the bacterial pathogens were inoculated. The buffer solution was used as a control. All experiments were conducted using 10 plants with three replicates for each treatment.

Inoculum preparation of bacterial pathogen. The inocula of two bacterial pathogens, B. glumae KACC 10359 and $X$. oryzae pv. oryzae KACC 10208 were prepared using the cell suspension after cultivation in R2A and YGC media, respectively, at $28^{\circ} \mathrm{C}$ for $24 \mathrm{~h}$ on a rotary shaker $(160 \mathrm{rpm})$. The culture broth of B. glumae was centrifuged $(5,000 \mathrm{~g}, 10 \mathrm{~min})$ and cell pellets were suspended in buffer solution (10 $\left.\mathrm{mM} \mathrm{MgSO}_{4}\right)$ adjusted to $6 \times 10^{7} \mathrm{cfu} / \mathrm{ml}$. A pin-prick bioassay was conducted for inoculation of the suspension of B. glumae. A bundle of 3-4 pins/needles was dipped into the suspension and then leaves were teased with the needles of bundle. Disease severity was evaluated 5 days after inoculation of the pathogen to the 5-week-old rice seedlings using a 0-3 disease rating scales: $0=$ symptomless, $1=$ slight infection, few small lesions, 2 = coalesced lesions to browning all over, and 3 = no description available (Cottyn et al., 1996). In case of bacterial blight, the suspension of $X$. oryzae pv. oryzae was prepared following the same procedure of $B$. glumae and concentration was adjusted to $1.2 \times 10^{7} \mathrm{cfu} /$ $\mathrm{ml}$. A clipping bioassay for bacterial blight was conducted using scissors that were dipped into the suspension and then used to cut the upper leaves. Disease severity was determined 7 days after inoculation according to a 1-9 scale (Misra et al., 1994). Disease reduction was calculated following the formula: [(disease severity of the control disease severity of a treatment) / disease severity of the control] $\times 100 \%$.

Measurement of growth promotion. Growth promotion of rice by treatment with a bacterial suspension of strain YC7007 $\left(2 \times 10^{7} \mathrm{cfu} / \mathrm{ml}\right)$ was examined during cultivation periods. Bacterial suspension $(1 \mathrm{ml})$ of YC7007 was drenched on the rhizosphere of 5-day-old rice seedlings in test tubes (18 cm length) containing $10 \mathrm{ml} \mathrm{1/2} \mathrm{MS}$ media with $0.8 \%$ agar. Growth data were recorded after 7 days of the bacterial treatment (12 days old). In case of the pot tests, 2-week-old seedlings were transplanted into plastic pots containing about $150 \mathrm{~g}$ autoclaved nursery soil and the bacterial suspension $(15 \mathrm{ml})$ was drenched at 7 days from transplanting. Growth data were recorded 
after 9 days of the bacterial treatment (30-day-old plants). Again, the bacterial suspension $(15 \mathrm{ml})$ was drenched at the tillering stage (30 days old) and growth data were recorded at the booting stage after 40 days of bacterial treatment from the tillering stage ( 70 days old). Ten plants with three replicates for each treatment were conducted for growth promotion activities for the test tubes and pot tests. The buffer solution (10 $\left.\mathrm{mM} \mathrm{MgSO}_{4}\right)$ was used for the control treatment.

Phylogenetic analysis based on 16S rRNA gene sequences and DNA-DNA hybridization. The 16S rRNA gene was amplified from the genomic DNA extracted with a commercial extraction kit (Intron Biotech, Seoul, Korea) using bacterial universal primers $27 \mathrm{~F}$ and 1492R and the purified PCR product was sequenced by GenoTech Inc. (Daejeon, Korea) (Lane, 1991). To ascertain the phylogenetic position of the novel endophytic bacteria and other closely related type strains, the $16 \mathrm{~S}$ rRNA gene sequences of the strains were compared with sequences obtained from NCBI and the EzTaxon-e database server (Kim et al., 2012). Multiple alignments of the sequences were performed using the CLUSTAL_X software (Thompson et al., 1997). Gaps were edited using the BioEdit program (Hall, 1999). The neighbor-joining method (Saitou and Nei, 1987), maximum-parsimony (Fitch, 1972), and maximumlikelihood algorithms in the MEGA 5.10 software (Tamura et al., 2011) were used to construct phylogenetic trees with bootstrap values based on 1,000 replications (Felsenstein, 1985). To determine the DNA-DNA relatedness values among strains, DNA-DNA hybridization was carried out using the DIG DNA labeling and detection kit (Roche Applied Science) according to the instructions of the manufacturer and the method described previously (Lee et al., 2011).

Morphological, phenotypic and chemotaxonomical characteristics. Cell morphology was observed under a light microscope (Nikon) at $1000 \times$ magnification and the presence of a flagellum was investigated by transmission electron microscopy (Hitachi, model H-600) using a cell broth grown at $28^{\circ} \mathrm{C}$ for $24 \mathrm{~h}$ in $\mathrm{R} 2 \mathrm{~A}$ medium. Gram reaction was determined using the bioMérieux Gram stain kit according to the manufacturer's instruction. The hydrolysis tests of strains were performed by a standard protocol, using casein, esculin, gelatin, starch, L-tyrosine, urea, Tween 20, and Tween 80 (Reichenbach, 1992; Smibert and Krieg, 1994). Enzyme activities, acid production from different carbohydrates, assimilation of various substrates and growth on carbohydrates were determined using commercial systems-API ZYM, API 20E, API 20NE, and API 50CH kits, respectively, at $28^{\circ} \mathrm{C}$ according to the manufacturer's instructions (BioMeriéux). Growth at different temperatures and various $\mathrm{pH}$ values $(\mathrm{pH}$ 4.0-14.0 at intervals of $0.5 \mathrm{pH}$ units) was investigated after 5 days incubation on R2A broth using appropriate buffers (Xu et al., 2005). Salt tolerance was tested in R2A broth supplemented with $1-14 \%(\mathrm{w} / \mathrm{v}$, at $1 \%$ intervals) $\mathrm{NaCl}$ after 5 days incubation at $28^{\circ} \mathrm{C}$. Duplicate antibiotic-sensitivity tests were performed using filter-paper disc diffusion assays with different antibiotics: $10 \mu \mathrm{g}$ ampicillin, $30 \mu \mathrm{g}$ chloramphenicol, $10 \mu \mathrm{g}$ penicillin, $10 \mu \mathrm{g}$ gentamycin, 30 $\mu \mathrm{g}$ kanamycin, $30 \mu \mathrm{g}$ vancomycin, $30 \mu \mathrm{g}$ streptomycin, and $30 \mu \mathrm{g}$ tetracycline (Yasir et al., 2010). Preparation of cell walls and analyses of peptidoglycans were carried out using methods described by Schleifer (1985) with the modification that TLC was performed on cellulose sheets rather than by paper chromatography. For the analysis of cellular fatty acids, bacterial strains were cultivated in R2A broth at $28^{\circ} \mathrm{C}$ and the microbial cells were harvested in the midexponential growth phase $\left(\mathrm{OD}_{600}=0.4-0.5\right)$. The analysis of fatty acid methyl esters was performed according to the instruction of the microbial identification system (MIDI; Microbial ID, Inc.). Extracts were analyzed by GC (Agilent 6890) and identified by comparing the fatty acid profiles with the TSBA 40 database provided with the Sherlock software (ver. 4.0). Amino acids of whole-cell hydrolysates of bacterial strains were extracted and analyzed according to the method of Staneck and Roberts (1974). Isoprenoid quinones were extracted and analyzed using reverse-phase HPLC according to the method described by Komagata and Suzuki (1987). For the measurement of $\mathrm{G}+\mathrm{C}$ content of the chromosomal DNA, the genomic DNA of strain YC7010 ${ }^{\mathrm{T}}$ was extracted and purified as described (Ausubel et al., 1995). It was then enzymatically degraded into nucleosides and $\mathrm{G}+\mathrm{C}$ content was determined with a reversephase C18 column (Mesbah et al., 1989). Polar lipids were extracted by the modified method of Minnikin et al. (1984) and separated by TLC on Merck Kieselgel 60-HPTLC. Aminolipids were detected by spraying the plate with $0.2 \%$ $(\mathrm{w} / \mathrm{v})$ solution of ninhydrin in butanol saturated with water followed by heating at $105^{\circ} \mathrm{C}$ for $10 \mathrm{~min}$ (Ross et al., 1985). Phospholipids were detected by spraying the plate with Zinzadze reagent of Dittmer and Lester (1964). Glycolipids were detected with 1-naphthol spray reagent by heating at $100^{\circ} \mathrm{C}$ for $3-5 \mathrm{~min}$ (Jacin and Mishkin, 1965). The presence of phosphatidylcholine was detected with Dragendorff reagent (Sigma-Aldrich; St. Louis, Mo). Total lipid profiles were detected by spraying with phosphomolybdic acid solution (Sigma-Aldrich; St. Louis, Mo) followed by heating 
at $150^{\circ} \mathrm{C}$ for $10 \mathrm{~min}$.

Statistical analysis. Data were analyzed by analysis of variance designed with a complete randomized single factor for in vitro, complete randomized block design for in vivo, and mean differences were compared using Duncan's multiple range test (DMRT). The SPSS software (ver. 17; SPSS Inc. in Chicago) was used for all analyses.

\section{Results}

Antagonistic activity of isolated strains. Among 250 bacterial strains isolated from the roots of rice plants, 15 endospore-forming bacteria showed inhibitory activity in the range of 2 to $>20 \mathrm{~mm}$ to the mycelial growth of $F$. fujikuroi. These bacteria were found to be closely related to Paenibacillus polymyxa, Bacillus siamensis, Paenibacillus jamilae, Bacillus methylotrophicus, Bacillus thuringiensis, B. cereus, Bacillus simplex, and Bacillus daliensis, based on 16S rRNA gene sequences. These isolates were tentatively identified and their similarities were in the range of $99.27 \%-100 \%$ with the closely related genera. Of the isolates, two strains especially, YC7007 and $\mathrm{YC} 7010^{\mathrm{T}}$, with the highest similarity to $\mathrm{B}$. siamensis showed strong antagonistic activity ( $>20 \mathrm{~mm}$ inhibition zone) against $F$. fujikuroi (Table 1). YC7007 also showed strong antagonistic activity against other rice pathogens,
B. oryzae, M. grisea, F. fukikuroi, and other major plant pathogens, with inhibition zones from 10 to $29 \mathrm{~mm}$ on PDA (Table 2). The culture filtrate of strain YC7007 prepared from different cultivation times also showed good growth inhibition against $F$. fujikuroi and two major seedborne bacterial pathogens of rice, B. glumae and X. oryzae pv. oryzae (Fig. 1). The culture filtrate of $60 \mathrm{~h}$-old broth had the strongest activity against three pathogens on the

Table 2. Antagonistic activity of endophytic strain YC7007 against important fungal and oomycete plant pathogens

\begin{tabular}{lc}
\hline \multicolumn{1}{c}{ Plant pathogens } & Inhibition zone $^{\mathrm{a}}(\mathrm{mm})$ \\
\hline Fusarium fujikuroi KACC 44022 & $28.0 \pm 0.6$ \\
Magnaporthe grisea KACC 40415 & $29.0 \pm 0.6$ \\
Bipolaris oryzae KACC 40853 & $27.6 \pm 0.3$ \\
Rhizoctonia solani KCTC 40101 & $23.6 \pm 0.3$ \\
Sclerotinia sclerotiorum GSCC 50501 & $28.0 \pm 0.6$ \\
Botrytis cinerea KCTC 6973 & $27.3 \pm 0.3$ \\
Fusarium oxysporum KCTC 16909 & $25.0 \pm 0.6$ \\
Botryosphaeria dothidea GSCC 50201 & $24.6 \pm 0.3$ \\
Pythium ultimum GSCC 50651 & $28.3 \pm 0.3$ \\
Alternaria panax KACC 42461 & $10.0 \pm 0.6$ \\
\hline
\end{tabular}

${ }^{a}$ The antagonistic activity was determined by an in vitro confrontation bioassay on PDA. The inhibition zone between mycelia of the pathogen and the border line of YC7007 was measured 7 days after incubation at $28^{\circ} \mathrm{C}$ and $20^{\circ} \mathrm{C}$ (S. sclerotiorum and B. cinerea). Data represent the average of three replicates.

Table 1. Identification of endophytic bacteria antagonistic to the bakanae pathogen of Fusarium fujikuroi

\begin{tabular}{|c|c|c|c|}
\hline \multirow{2}{*}{ Origin } & \multirow{2}{*}{ Closely related strain } & \multirow{2}{*}{$\begin{array}{c}\% \\
\text { Identity }^{\mathrm{a}}\end{array}$} & \multirow{2}{*}{$\begin{array}{c}\text { Inhibition }^{\mathrm{b}} \\
\text { Fusarium fujikuroi }\end{array}$} \\
\hline & & & \\
\hline YC7005 & Paenibacillus polymyxa (AFOX01000032) & 99.77 & + \\
\hline YC7006 & Paenibacillus polymyxa (AFOX01000032) & 99.77 & + \\
\hline YC7007 & Bacillus siamensis (AJVF01000043) & 99.67 & ++++ \\
\hline YC7008 & Paenibacillus polymyxa (AFOX01000032) & 99.27 & + \\
\hline YC7009 & Paenibacillus jamilae (AJ271157) & 100 & + \\
\hline $\mathrm{YC} 7010^{\mathrm{T}}$ & Bacillus siamensis (AJVF01000043) & 99.67 & +++ \\
\hline YC7012 & Bacillus siamensis (AJVF01000043) & 99.60 & ++ \\
\hline YC7013 & Bacillus methylotrophicus (EU194897) & 99.37 & ++ \\
\hline YC7014 & Bacillus methylotrophicus (EU194897) & 99.62 & ++ \\
\hline YC7015 & Bacillus methylotrophicus (EU194897) & 99.68 & ++ \\
\hline YC7016 & Bacillus methylotrophicus (EU194897) & 99.64 & ++ \\
\hline YC7022 & Bacillus thuringiensis (ACNF010000156) & 99.87 & ++ \\
\hline YC7023 & Bacillus cereus (AE016877) & 100 & ++ \\
\hline YC7025 & Bacillus simplex (AB363738) & 98.88 & ++ \\
\hline YC7027 & Bacillus daliensis (ACNF010000156) & 100 & ++ \\
\hline
\end{tabular}

${ }^{a}$ Based on the partial 16S rRNA gene sequences analysis.

${ }^{b}$ The mycelial growth of a pathogen by antagonistic bacteria was determined as inhibition zone on PDA. $+: 2-10,++: 10-15,+++: 15-20$, and ++++ : $>20 \mathrm{~mm}$. 


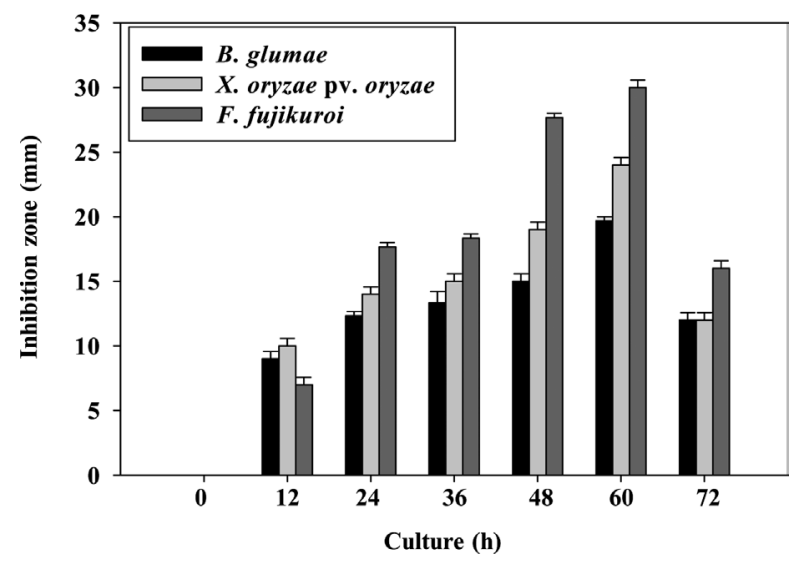

Fig. 1. Growth inhibition of major seed-borne rice pathogens (Bulkholderia glumae, Xanthomonas oryzae pv. oryzae, and Fusarium fujikuroi) by the culture filtrate of strain YC7007 at different culture times.

respective culture media with the inhibition zone of $30 \mathrm{~mm}$, $24 \mathrm{~mm}$ and $19.7 \mathrm{~mm}$ for F. fujikuroi, X. oryzae pv. oryzae and $B$. glumae, respectively.

Induction of systemic resistance against panicle blight and bacterial blight. Strain YC7007 was investigated for the activity of inducing systemic resistance to the panicle blight and bacterial blight of rice. Drenching of three different concentrations of YC7007 to soils at $5.6 \times 10^{5}, 3.6 \times 10^{6}$, and $2 \times 10^{7} \mathrm{cfu} / \mathrm{ml}$ revealed significantly lower disease severity index of the leaf rot $(p<0.05)$ by $1.4,0.9$, and 0.8 , respectively, than the control, 2.5 (Fig. 2). However, there was no significant difference in the disease severity between bacterial concentrations of $10^{6}$ and $10^{7} \mathrm{cfu} / \mathrm{ml}$. The concentration $\left(2 \times 10^{7}, \mathrm{cfu} / \mathrm{ml}\right)$ of strain YC7007 drenched to the rhizosphere soils showed good control efficacy against panicle blight and bacterial blight, by $65.2 \%$ and $61.2 \%$, respectively. Its culture filtrate sprayed to the leaves also showed significantly lower disease severity than the control, with disease reduction by $70.8 \%$ and $70.5 \%$ for panicle blight and bacterial blight, respectively (Table 3). The strain YC7007 showed significantly lower disease severity $(p<0.01)$ against panicle blight and bacterial blight than the control.

Growth promotion by YC7007. Strain YC7007 had growth promoting activity with significantly $(p<0.05)$ better growth than the control at all stages tested such as the seedling, tillering, and booting stages of rice. Treatment with the bacterial suspension $\left(2 \times 10^{7} \mathrm{cfu} / \mathrm{ml}\right)$ to the rhizosphere of the rice increased shoot length from 11.67 $\mathrm{cm}$ to $19.33 \mathrm{~cm}$ in the test tube at the seedling stage, 36.45
A

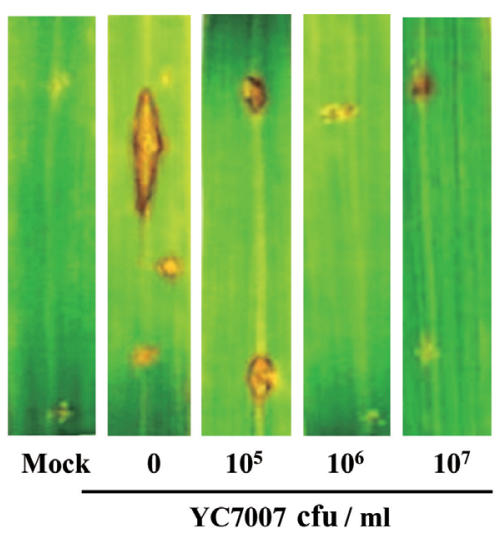

B

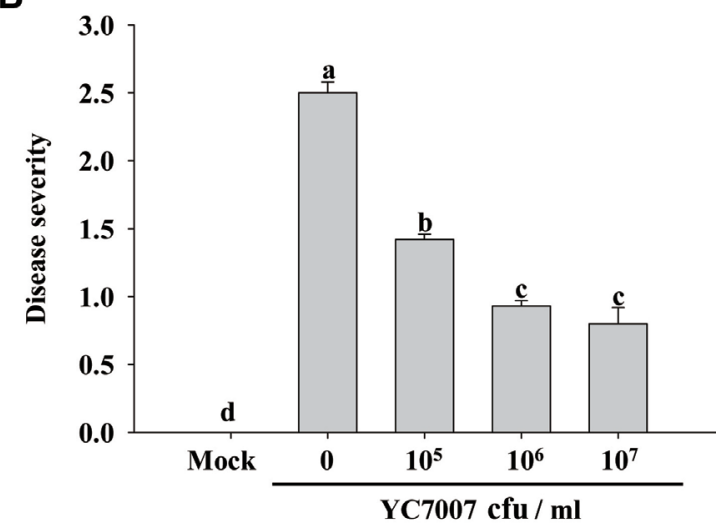

Fig. 2. Effect of YC7007 drenching in the rice rhizosphere on disease severity of panicle blight caused by Bulkholderia glumae. (A) Necrotic lesions developed at 5 days after inoculation of pathogen at $30^{\circ} \mathrm{C}$. (B) Cell suspension of YC7007 $(15 \mathrm{ml})$ at different concentrations was drenched to the pots containing autoclaved soil $(150 \mathrm{~g}) 5$ days before inoculation of the bacterial pathogen. The pathogen was challenged by pin-prick inoculation in each treatment (20 leaves) with three replicates. Different letters indicate values that are significantly different $(P<0.05)$ by Duncan's multiple range test. 'Mock' means no inoculation of the pathogen.

$\mathrm{cm}$ to $46.33 \mathrm{~cm}$, and $55.33 \mathrm{~cm}$ to $61.0 \mathrm{~cm}$ in the tillering and booting stages, respectively. The length of primary roots increased from $2.67 \mathrm{~cm}$ to $7.67 \mathrm{~cm}$ at the seedling stage and the numbers of tillers were also increased, from 1.9 to 2.9 at the tillering stage and 5.3 to 7.0 at the booting stage (Table 4).

Identification of two antagonistic bacteria $\mathrm{YC7007}$ and $\mathrm{YC7010}^{\mathrm{T}}$. Two endophytic strains YC7007 and YC $7010^{\mathrm{T}}$ with the strongest antagonistic activity out of 15 antagonistic bacteria were identified using a polyphasic approach. The 16S rRNA gene sequence of the two strains was a continuous stretch of 1513 base pairs, which aligned 
Table 3. Suppression of panicle blight and bacterial leaf blight of rice by YC7007

\begin{tabular}{cccccc}
\hline Treatment $^{\mathrm{a}}$ & \multicolumn{2}{c}{ Disease severity } & & \multicolumn{2}{c}{ \% Disease reduction } \\
\cline { 2 - 3 } \cline { 5 - 6 } Pathogen $^{\mathrm{b}}$ & B. glumae & X. oryzae pv. oryzae & & B. glumae & X. oryzae pv. oryzae \\
\hline Control & $2.50 \pm 0.08 \mathrm{a}$ & $5.67 \pm 0.13 \mathrm{a}$ & & - & - \\
YC7007 (suspension) & $0.87 \pm 0.12 \mathrm{~b}$ & $2.20 \pm 0.23 \mathrm{~b}$ & & 65.2 & 61.2 \\
YC7007 (culture filtrate) & $0.73 \pm 0.07 \mathrm{~b}$ & $1.67 \pm 0.13 \mathrm{bc}$ & & 70.8 & 70.5 \\
\hline
\end{tabular}

${ }^{a}$ The cell suspension $15 \mathrm{ml}\left(2 \times 10^{7} \mathrm{cfu} / \mathrm{ml}\right)$ was drenched to the pots 5 days before inoculation of the bacterial pathogen. Culture filtrate prepared with $60 \mathrm{~h}$ old culture broth was diluted 10 times with $10 \mathrm{mM} \mathrm{MgSO}_{4}$ and sprayed to the leaves as droplets before 5 days of pathogen inoculation. Control plants were sprayed with only the buffer solution $\left(10 \mathrm{mM} \mathrm{MgSO}_{4}\right)$.

${ }^{b}$ The inoculation techniques for panicle blight and bacterial blight was conducted by pinprick and clipping assay, respectively, described details in the Materials and Methods. Different letters indicate values that are significantly different $(P<0.01)$ by Duncan's multiple range tests. Mean $\pm \mathrm{SE}$; standard error was calculated using 10 plants with three replicates for each treatment.

Table 4. Effect of YC7007 on the growth promotion of rice at different growing stages

\begin{tabular}{|c|c|c|c|c|c|c|}
\hline \multirow{3}{*}{ Treatment } & \multicolumn{6}{|c|}{ Growth promoting activity } \\
\hline & \multicolumn{2}{|c|}{ Seedling stage $\mathrm{e}^{\mathrm{a}}$} & \multicolumn{2}{|c|}{ Tillering stage $\mathrm{e}^{\mathrm{b}}$} & \multicolumn{2}{|c|}{ Booting stage $^{c}$} \\
\hline & Shoot length $(\mathrm{cm})$ & Root length $(\mathrm{cm})$ & Shoot length $(\mathrm{cm})$ & Tiller no. & Shoot length $(\mathrm{cm})$ & Tiller no. \\
\hline Control & $11.67 \pm 0.33 b$ & $2.67 \pm 0.33 b$ & $36.45 \pm 1.18 b$ & $1.89 \pm 0.22 b$ & $55.33 \pm 0.33 b$ & $5.33 \pm 0.67 \mathrm{~b}$ \\
\hline YC7007 & $19.33 \pm 0.33 \mathrm{a}$ & $7.67 \pm 0.33 \mathrm{a}$ & $46.33 \pm 2.0 \mathrm{a}$ & $2.89 \pm 0.11 \mathrm{a}$ & $61.0 \pm 2.00 \mathrm{a}$ & $7.00 \pm 0.58 \mathrm{a}$ \\
\hline
\end{tabular}

${ }^{\mathrm{a}}$ Bacterial suspension $(1 \mathrm{ml})$ of YC7007 $\left(2 \times 10^{7} \mathrm{cfu} / \mathrm{ml}\right)$ was inoculated with 5 -day-old seedlings in the test tube.

${ }^{\mathrm{b}} 5 \mathrm{ml}$ of $\mathrm{YC} 7007\left(2 \times 10^{7} \mathrm{cfu} / \mathrm{ml}\right)$ was drenched to 21-day-old seedlings in pots and data were recorded after 9 days of bacterial treatment.

${ }^{\mathrm{c}} 5 \mathrm{ml}$ of YC7007 $\left(2 \times 10^{7} \mathrm{cfu} / \mathrm{ml}\right)$ was drenched once again to 30-day-old seedlings in pots. Data were recorded after 40 days of bacterial treatment. Control plants of all stages were treated with the buffer solution $\left(10 \mathrm{mM} \mathrm{MgSO}_{4}\right)$ as the same amount of the corresponding treatments by the YC7007. Different letters indicate statistically significant differences between treatments by Student's $t$-test. Mean \pm SE; standard error was calculated using 10 plants with three replicates for each treatment.

identically except only one nucleotide, with the database accession numbers KP203893 (YC7007) and KP201498 $\left(\mathrm{YC} 7010^{\mathrm{T}}\right)$ in GenBank/EMBL/DDBJ. Based on the comparative 16S rRNA gene sequence analysis, the two strains are in the same clade with the same branch length of the phylogenetic tree, showing the highest similarity to B. siamensis KACC $15859^{\mathrm{T}}$ (99.67\%), B. methylotrophicus KACC $13105^{\mathrm{T}}(99.65 \%)$, B. amyloliquefaciens subsp. plantarum KACC $17177^{\mathrm{T}}(99.60 \%)$, and B. tequilensis KACC $15944^{\mathrm{T}}$ (99.45\%) (Table 1, Fig. 3). The DNA-DNA relatedness value between strain $\mathrm{YC} 7010^{\mathrm{T}}$ and its most closely related strain $B$. siamensis KACC $15859^{\mathrm{T}}$ was $50.4 \pm 3.5$, but it was $91.5 \pm 11.0 \%$ between $\mathrm{YC} 7007$ and YC7010 ${ }^{\mathrm{T}}$ (Table 5). Both strains were Gram-positive, motile, rod-shaped, and grew well at $13-60^{\circ} \mathrm{C}$ (optimum at $28-30^{\circ} \mathrm{C}$ ) and $\mathrm{pH}(4-12)$ (optimum at $\mathrm{pH}$ 7). Strains were able to grow at 0.1 TSA media with $1-13 \% \mathrm{NaCl}$ $(\mathrm{w} / \mathrm{v})$, but $\mathrm{NaCl}$ was not required for growth. Strains were resistant to chloramphenicol by $30 \mu \mathrm{g} / \mathrm{ml}$. Strains contained meso-diaminopimelic acid as the diagnostic diamino acid in the cell-wall peptidoglycan and MK-7 as a major respiratory quinone system. Other physiological and biochemical characteristics of two strains YC7007 and YC7010 are summarized in Table 6. The major fatty acids of the strains YC7007 and $\mathrm{YC} 7010^{\mathrm{T}}$ were the anteiso- $\mathrm{C}_{15: 0}(38.4$ and $32.0 \%)$ and iso $\mathrm{C}_{15: 0}(28.1$ and $27.7 \%)$, respectively. The other cellular fatty acids profiles of $\mathrm{YC} 7010^{\mathrm{T}}$ consisted of $\mathrm{C}_{16: 0}(7.7 \%)$, iso $\mathrm{C}_{17: 0}(6.4 \%)$, anteiso- $\mathrm{C}_{17: 0}(5.3 \%)$, iso $\mathrm{C}_{16: 0}(5.2 \%), \mathrm{C}_{18: 0}(5.1 \%), \mathrm{C}_{16: 1} \omega 7 c$ alcohol (3.4\%), iso $\mathrm{C}_{14: 0}$ (2.9\%), iso- $\mathrm{C}_{17: 1} \omega 10 c(1.7 \%), \mathrm{C}_{16: 1} \omega 11 c(1.4 \%), \mathrm{C}_{14: 0}(1.1 \%)$, and $\mathrm{C}_{20: 1} \omega 7 c(0.2 \%)$ (Table 7$)$. The $\mathrm{G}+\mathrm{C}$ contents of the genomic DNA of two strains YC7007 and YC7010 ${ }^{\mathrm{T}}$ were $50.5 \mathrm{~mol} \%$ and $51.2 \mathrm{~mol} \%$, respectively. Strains exhibited a polar lipid profile consisting of phosphatidylethanolamine (PE), phosphatidylglycerol (PG), diphosphatidylglycerol (DPG), unknown glycolipid (GL) and unknown aminolipids (AL1-2) (Fig. S1). Based on 16S rRNA gene sequence analysis, DNA-DNA relatedness value, fatty acid composition and biochemical and physiological characteristics, strains YC7007 and $\mathrm{YC} 7010^{\mathrm{T}}$ represent a novel species of the genus Bacillus, for which the name Bacillus oryzicola sp. nov. is proposed.

Description of Bacillus oryzicola YC7010 ${ }^{\mathrm{T}}$ sp. nov. Bacillus oryzicola (o.ry.zi'co.la L. fem. n. oryz, rice; L. v. colere, to inhabit; L. adj. oryzicola, living in rice). Cells are Gram- 


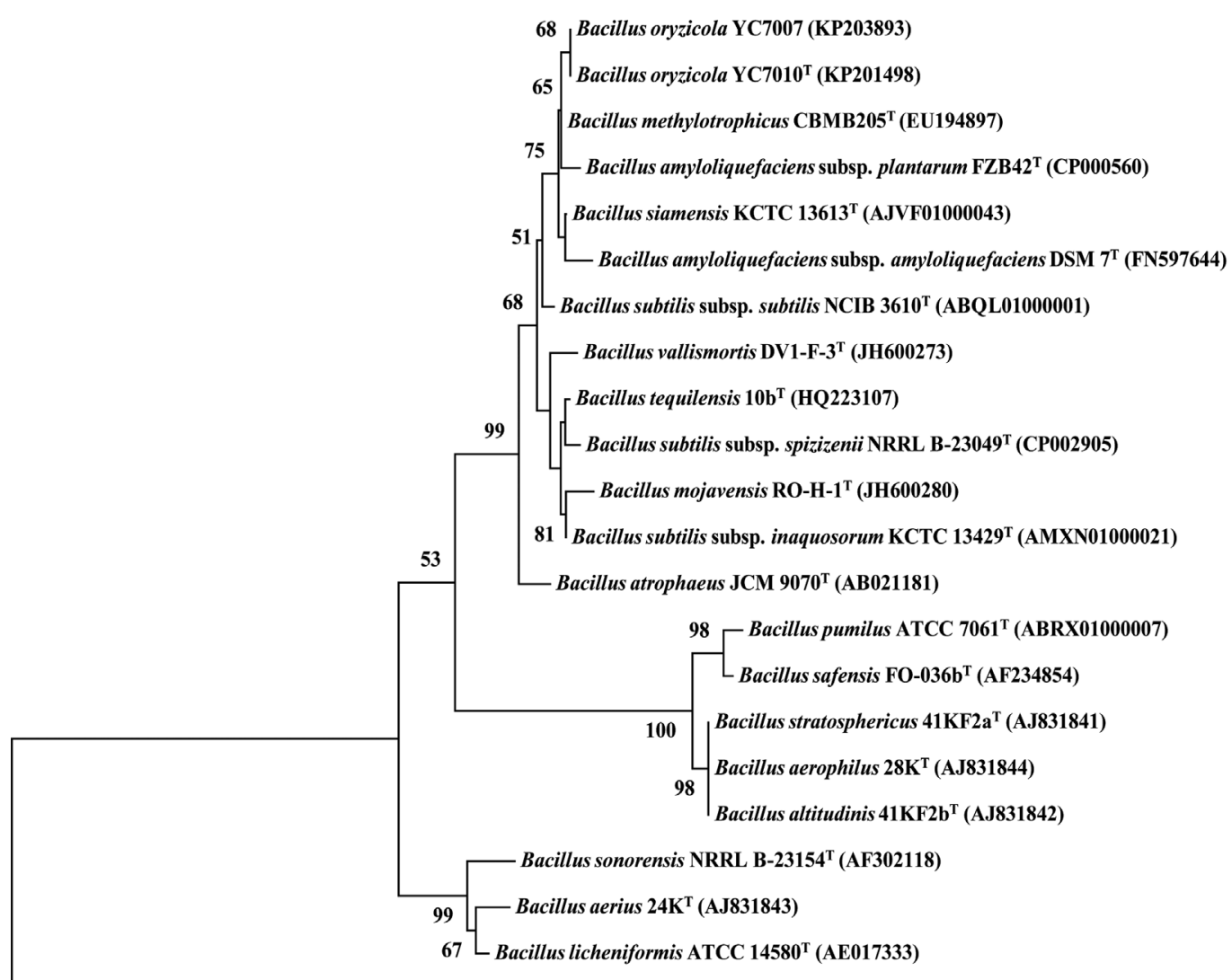

Geobacillus stearothermophilus NBRC $12550^{\mathrm{T}}$ (AJ294817)

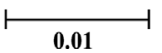

Fig. 3. Phylogenetic tree constructed from the comparative analysis of 16S rRNA gene sequences showing the relationship of strains YC7007 and YC7010 ${ }^{\mathrm{T}}$ with other related taxa. The phylogenetic tree was constructed using the neighbor-joining method and the Jukes \& Cantor evolutionary distance matrix data obtained from aligned nucleotides. Bootstrap values (expressed as percentage of 1,000 replications) greater than $50 \%$ are shown at the branch points.

positive, rod-shaped $(0.8-0.9 \times 2.0-3.0 \mu \mathrm{m})$. Colonies grown on R2A agar at $28^{\circ} \mathrm{C}$ for 2 days are white-cream, circular, and flat elevation with an entire margin. Cells are motile with a single polar flagellum. The cell wall contains meso-diaminopimelic acid as the diagnostic diamino acid. Cells usually occur singly or in pairs that are catalasepositive and oxidase-negative. Cells grow at $13-60^{\circ} \mathrm{C}$ and at $\mathrm{pH} 4-12.0$. Hydrolysis of casein and gelatin is positive while negative for starch, Tween 20, Tween 80, tyrosine, and carboxymethyl cellulose. It uses D-glucose, D-fructose, D-mannose, D-mannitol, methyl- $\alpha$-D-glucopyranoside, $\mathrm{N}$-acetyl-glucosamine, amygdalin, arbutin, esculin ferric citrate, salicin, D-celiobiose, D-maltose, D-lactose, D-saccharose, D-trehalose, D-raffinose, starch, glycogen, gentiobiose, trisodium citrate, and Kohn's gelatin. With the API ZYM kit, it showed enzymatic activities of esterase (C4),

Table 5. DNA-DNA hybridization values of $Y C 7010^{\mathrm{T}}$ with closely related strains

\begin{tabular}{lc}
\multicolumn{1}{c}{ Strains } & \% DNA-DNA hybridization \\
\hline YC7007 & $91.5 \pm 11.0$ \\
B. siamensis KACC $15859^{\mathrm{T}}$ & $50.4 \pm 3.5$ \\
B. methylotrophicus KACC $13105^{\mathrm{T}}$ & $48.7 \pm 9.4$ \\
B. subtilis subsp. inaquosorum KACC $17047^{\mathrm{T}}$ & $47.4 \pm 4.0$ \\
B. amyloliquefaciens subsp. plantarum KACC $17177^{\mathrm{T}}$ & $41.9 \pm 7.9$ \\
B. tequilensis KACC 15944 & $37.9 \pm 5.7$ \\
\hline
\end{tabular}


Table 6. Differential phenotypic characteristics between strains YC7007 and YC7010 ${ }^{\mathrm{T}}$ and closely related species of the genus Bacillus

\begin{tabular}{|c|c|c|c|c|c|c|c|}
\hline Characteristic & ${ }^{\mathrm{a}} 1$ & 2 & 3 & 4 & 5 & 6 & 7 \\
\hline Growth at $\mathrm{pH} 13$ & - & + & - & - & - & + & + \\
\hline Growth at $14 \% \mathrm{NaCl}$ & - & - & - & - & - & - & + \\
\hline \multicolumn{8}{|l|}{ Hydrolysis of } \\
\hline Gelatin & + & - & + & + & + & + & + \\
\hline Carboxymethyl cellulose & - & - & - & - & + & - & - \\
\hline \multicolumn{8}{|l|}{ API kits } \\
\hline Arbutin & + & w & - & $\mathrm{w}$ & + & $\mathrm{w}$ & + \\
\hline D-Lactose & + & $\mathrm{w}$ & $\mathrm{w}$ & $\mathrm{w}$ & - & $\mathrm{w}$ & - \\
\hline Starch & + & w & - & $\mathrm{w}$ & $\mathrm{w}$ & - & + \\
\hline Glycogen & + & $\mathrm{w}$ & - & $\mathrm{w}$ & $\mathrm{w}$ & $\mathrm{w}$ & + \\
\hline Gentiobiose & + & $\mathrm{w}$ & - & - & - & - & + \\
\hline D-Turanose & - & - & $\mathrm{w}$ & - & - & - & - \\
\hline Potassium-5-ketogluconate & - & - & $\mathrm{w}$ & - & - & - & - \\
\hline Alkaline phosphatase & $\mathrm{w}$ & + & + & + & - & + & + \\
\hline Acid phosphatase & $\mathrm{w}$ & $\mathrm{w}$ & - & - & - & + & - \\
\hline Naphtol-AS-BI-phosphohydrolase & + & - & - & + & + & + & + \\
\hline$\alpha$-Glucosidase & - & - & + & - & - & - & - \\
\hline $\mathrm{N}$-acetyl- $\beta$-glucosaminidase & + & + & + & - & - & - & - \\
\hline$\alpha$-Mannosidase & - & - & $\mathrm{W}$ & - & - & - & - \\
\hline $\mathrm{G}+\mathrm{C}$ content $(\mathrm{mol} \%)$ & 50.5 & 51.2 & $41.4^{\mathrm{b}}$ & $45^{\mathrm{c}}$ & ND & ND & ND \\
\hline
\end{tabular}

${ }^{\mathrm{a}}$ Taxa: 1, strain YC7007; 2, strain YC7010 ${ }^{\mathrm{T}} ; 3$, B. siamensis KACC $15859^{\mathrm{T}} ; 4$, B. methylotrophicus $\mathrm{KACC} 13105^{\mathrm{T}}$; 5, B. subtilis subsp. inaquosorum KACC $17047^{\mathrm{T}}$; 6, B. amyloliquefaciens subsp. plantarum KACC $17177^{\mathrm{T}}$; 7, B. tequilensis $\mathrm{KACC} 15944^{\mathrm{T}}$. +: positive; -: negative; w: weakly positive; ND: not determined. Data for the related type strains are from this study unless indicated.

bumpavapol et al., 2010.

'Madhaiyan et al., 2010.

esterase lipase (C8), naphthol-AS-Bl-phosphohydrolase, and $\mathrm{N}$-acetyl- $\beta$-glucosaminidase, but not lipase (C-14), leucine arylamidase, valine arylamidase, cystine arylamidase, trypsin, $\alpha$-chymotrypsin, $\alpha$-galactosidase, $\beta$-galactosidase, $\beta$-glucosidase, $\alpha$-mannosidase, and $\alpha$-fucosidase. It was resistant to $30 \mu \mathrm{g}$ of chloramphenicol and streptomycin, but susceptible to $10 \mu \mathrm{g}$ of ampicillin, penicillin, gentamycin, and $30 \mu \mathrm{g}$ of kanamycin, vancomycin, and tetracycline. Growth was observed in R2A broth containing 13\% (w/v) $\mathrm{NaCl}$ but not $14 \%(\mathrm{w} / \mathrm{v})$. The major quinone is MK-7. The polar lipids are phosphatidylethanolamine (PE), phosphatidylglycerol (PG), diphosphatidylglycerol (DPG), unknown glycolipid and unknown aminolipids. The DNA G $+\mathrm{C}$ content of the type strain is $51.2 \mathrm{~mol} \%$. The type strain, $\mathrm{YC} 7010^{\mathrm{T}}\left(=\mathrm{KACC} 18228^{\mathrm{T}}\right)$, was isolated from the root of rice in Jinju, Korea.

\section{Discussion}

Among many endophytic bacterial strains isolated from the rice roots, $6 \%$ of the Bacillus species were antagonistic and inhibited the mycelial growth of phytopathogens in this study. About $9 \%$ of endophytic bacteria including several Bacillus species and other Gram-negative bacteria isolated from tidal flat plants were antagonistic against oomycetous phytopathogens in a previous study (Bibi et al., 2012). Our strains, belonging to the genus Bacillus based on the 16S rRNA gene sequence, were examined for their antagonistic activity against the major rice fungal and bacterial pathogens in vitro and in vivo tests. Of these isolates, two strains $\mathrm{YC} 7007$ and $\mathrm{YC} 7010^{\mathrm{T}}$ with the highest similarity to B. siamensis showed strong antagonistic activity in suppressing mycelial growth of the bakanae pathogen, F. fujikuroi, one of the most important seedborne pathogens of rice. The culture filtrate of YC7007 also had strong inhibiting activity against bakanae, bacterial blight, and grain rot, suggesting that the strain may produce antifungal compounds. It has been reported that some Bacillus species produce small peptides and lipopeptides, such as fengycin, iturin, and surfactin, which have good suppression of phytopathogens (Bais et al., 2004; Crane et al., 2013; Dimkic et al., 2013). Drenching with a cell suspension of strain YC7007 suppressed the severity of panicle blight and bacterial blight of rice in pot tests, which 
Table 7. Cellular fatty acid composition (\%) of strains YC7007, YC7010 $0^{\mathrm{T}}$, and other related taxa

\begin{tabular}{|c|c|c|c|c|c|}
\hline Fatty acids & ${ }^{\mathrm{a}} 1$ & 2 & 3 & 4 & 5 \\
\hline $\mathrm{C}_{12: 0}$ & 1.7 & - & - & - & - \\
\hline $\mathrm{C}_{14: 0}$ & - & 1.1 & 0.7 & - & 1.1 \\
\hline $\mathrm{C}_{15: 0}$ & - & - & 8.2 & - & - \\
\hline $\mathrm{C}_{16: 0}$ & 6.1 & 7.7 & 3.3 & 5.1 & 4.1 \\
\hline $\mathrm{C}_{17: 0}$ & - & - & 0.9 & - & - \\
\hline $\mathrm{C}_{18: 0}$ & - & 5.1 & - & - & 1.1 \\
\hline iso- $\mathrm{C}_{14: 0}$ & 4.6 & 2.9 & 2.7 & 6.1 & 2.6 \\
\hline iso- $\mathrm{C}_{15: 0}$ & 28.1 & 27.7 & 30.7 & 28.8 & 31.9 \\
\hline iso- $\mathrm{C}_{16: 0}$ & 6.8 & 5.2 & 2.5 & 5.9 & 3.9 \\
\hline iso- $\mathrm{C}_{17: 0}$ & 6.4 & 6.4 & 5.6 & 6.9 & 7.6 \\
\hline iso- $\mathrm{C}_{17: 1} \omega 10 c$ & 2.0 & 1.7 & 1.6 & - & 2.6 \\
\hline anteiso- $\mathrm{C}_{15: 0}$ & 38.4 & 32.0 & 37.2 & 39.8 & 35.6 \\
\hline anteiso- $\mathrm{C}_{17: 0}$ & 5.9 & 5.3 & 4.7 & 7.6 & 5.8 \\
\hline $\mathrm{C}_{16: 1} \omega 7 c$ alcohol & - & 3.4 & - & - & 1.2 \\
\hline $\mathrm{C}_{16: 1} \omega 11 c$ & - & 1.4 & 2.0 & - & 1.5 \\
\hline $\mathrm{C}_{20: 1} \omega 7 c$ & - & 0.2 & - & - & - \\
\hline Summed feature $4 *$ & - & - & - & - & 1.1 \\
\hline
\end{tabular}

${ }^{\mathrm{a}}$ Taxa: 1, strain YC7007; 2, strain $\mathrm{YC} 7010^{\mathrm{T}} ; 3$, B. siamensis KACC $15859^{\mathrm{T}} ; 4$, B. methylotrophicus KACC $13105^{\mathrm{T}} ; 5, B$. amyloliquefaciens subsp. plantarum KACC $17177^{\mathrm{T}}$. - : not detected.*Summed features represent groups of two or three fatty acids that could not be separated by GLC with the MIDI system. Summed feature 4 contained $C_{17: 1}$ ISO I/ANTEI.

indicated the induction of systemic resistance. Disease severity of panicle blight was reduced by treatment with the strain YC7007 at $10^{5}(\mathrm{cfu} / \mathrm{ml})$ and higher concentrations between $10^{6}$ to $10^{7} \mathrm{cfu} / \mathrm{ml}$ suppressed disease, over $62 \%$. The culture filtrate of YC7007 also decreased panicle blight and bacterial blight significantly over $70 \%$ compared with the control. It was demonstrated that treatment with the cell suspension of B. subtilis $\left(2.5 \times 10^{8} \mathrm{cfu} / \mathrm{ml}\right)$ and $B$. cereus AR156 $\left(5 \times 10^{8} \mathrm{cfu} / \mathrm{ml}\right)$ controlled root and leaf speck diseases of Arabidopsis, respectively (Bais et al., 2004; Niu et al., 2011). The bacterial concentrations of these two isolates B. subtilis and B. cereus AR156 $\left(10^{8} \mathrm{cfu} / \mathrm{ml}\right)$ was over 100 times higher than that of strain YC7007 $\left(10^{6} \mathrm{cfu} / \mathrm{ml}\right)$, which may not be feasible for practical use at commercial farms. For developing antagonistic bacteria as biological agents, the optimal concentration of bacteria should be equal or lower than $10^{7} \mathrm{cfu} / \mathrm{ml}$, considering the dilution factor in the final use by farmers (Chen et al., 2009). As the bacterial suspension drenched to the rhizosphere of rice and culture filtrate sprayed on the leaves, had an antagonistic activity against the pathogens, strain YC7007 probably has indirect and/or direct interactions between them. Diseases of panicle blight and bacterial blight were controlled by the treatment - both drenching and spraying - suggesting that the strain YC7007 may react through induced systemic resistance (ISR) or systemic acquired resistance (SAR) for the suppression of the diseases (Ahn et al., 2007; Niu et al., 2011). The reaction mechanism needs to be determined in terms of the hormonal signaling via the salicylic, jasmonic, or ethylene pathways for SAR or ISR.

Several species of Bacillus have been commercialized as biological agents due to their long persistence in adverse environments over a long period. Some of these were functional in many plants, by inducing systemic resistance (Hu et al., 2011; Kloepper et al., 2004). B. vallismortis EXTN-1 and B. cereus have been used to control rice blast, sheath blight, and bakanae (Kazempour and Elahinia, 2007; Park et al., 2006). To our knowledge, this is the first report that Bacillus strain YC7007 has long-lasting activity in resistance induction in rice against major bacterial diseases of panicle blight and bacterial blight. Furthermore, strain YC7007 showed good growth promotion of rice by a onetime application of a bacterial suspension at the seedling stage, just after germination. YC7007 increased shoot and root length by 1.1-2.9 fold at the seedling, tillering, and booting stages, and increased tiller numbers by over 1.3fold at the tillering and booting stages compared with the control. This demonstrates that resistance-inducing and growth-promoting activity by the probiotic bacterium YC7007 could be long lasting, from the seedling to the booting stage (Picard et al., 2008). It has been reported that the induction of host resistance negatively affects host plants, in suppressing growth associated with the plant hormones, gibberellic acid (GA) and auxin. The immune system is mediated by brassinosteroids and salicylic acid, repressing GA and auxin responses, at least in part via negative cross talk with the hormone, respectively, in rice and Arabidopsis (De Vleesschauwer et al., 2012; Wang et al., 2007). A chemical derivative of salicylic acid (SA), benzothiadiazole (BTH), induced systemic resistance against biotrophic pathogens in rice, cucumber, Arabidopsis, and pepper plants via salicylic acid signaling networks, but it retarded the plant growth by inhibiting the auxin response. In contrast, some rhizobacteria, including Bacillus species, enhanced resistance induction with no negative effect on plant growth (Ahn et al., 2005; Ryu et al., 2004; Yang et al., 2009). In this respect, strain YC7007 may be a good candidate for developing a biocontrol agent with multiple functions of resistance induction and growth promotion in rice without negative effect. Additionally, strain YC7007 has anti-fungal and anti-bacterial activity, probably via production of antibiotics.

Our two endophytic strains, designated YC7007 and 
YC7010 ${ }^{\mathrm{T}}$, were further characterized based on a polyphasic study including 16S rRNA gene sequences, DNA-DNA hybridization, fatty acid analyses, and other physical and biochemical tests. The two strains were identified as novel species of the genus Bacillus, in the same clade with the same branch length in the phylogenetic tree. The overall percentage sequence divergences of the two strains were the same, but differed from the other closely related species in the clade of the phylogenetic tree. Strains YC7007 and $\mathrm{YC} 7010^{\mathrm{T}}$ showed $100 \%$ similarity and very high DNA-DNA relatedness values of $91.5 \%$ between them, indicating that the two strains are the same Bacillus species. The DNA-DNA hybridization values of other related strains B. siamensis, B. methylotrophicus, B. subtilis subsp. inaquosorum, $B$. amyloliquefaciens subsp. plantarum, and B. tequilensis in comparison to the type strain $\mathrm{YC}^{2} 010^{\mathrm{T}}$ were below $70 \%$, which indicated that $\mathrm{YC} 7010^{\mathrm{T}}$ was a novel species (Goris et al., 2007; Stackebrandt and Goebel, 1994). Additionally, the two strains showed almost the same reactions in physical and biochemical tests using API kits, but showed different responses to other reference strains, indicating that the two strains are distinct from other related Bacillus strains. In tolerance to $\mathrm{NaCl}$, the two strains can survive up to $13 \% \mathrm{NaCl}$, but $B$. methylotrophicus did not grow at $10 \% \mathrm{NaCl}$ (Madhaiyan et al., 2010). Major cellular fatty acids of YC7007 and $\mathrm{YC} 7010^{\mathrm{T}}$ were anteiso- $\mathrm{C}_{15: 0}$ and iso $\mathrm{C}_{15: 0}$, which are same as other related species of the genus Bacillus. Other minor fatty acids of the two strains differed from those of closely related Bacillus strains. Each bacterium has a specific fatty acid profile and fatty acid analysis is used as an effective tool in bacterial taxonomy (Kämpfer, 1994). The major isoprenoid quinones of strains YC7007 and $\mathrm{YC} 7010^{\mathrm{T}}$ were menaquinone-7 (MK-7) as those of the type strains of the genus Bacillus species (Kang et al., 2013). The DNA G+C contents of both strains were 50.5-51.2 mol\%, which are similar to but slightly higher than those of other Bacillus species (Madhaiyan et al., 2010; Sumpavapol et al., 2010). Major polar lipids of both strains were PE, PG, and DPG, which are in accordance with those of B. siamensis and $B$. songklensis (Kang et al., 2013; Sumpavapol et al., 2010).

Based on all the data from the polyphasic studies, the two strains YC7007 and YC7010 ${ }^{\mathrm{T}}$, belonged to the genus Bacillus; we therefore, proposed strain YC7010 ${ }^{\mathrm{T}}$ and YC7007 as a novel species and suggested the name Bacillus oryzicola YC7010 $\mathrm{sp}$. nov. with the type strain. In conclusion, the endophytic strain B. oryzicola YC7007 has multifunctional activities in rice: direct inhibition of fungal and bacterial pathogens, systemic resistance induction, and plant growth promotion, which could possibly be used practically as a microbial inoculant on commercial farms.

\section{Acknowledgments}

This work was supported by BK21 Plus (Ministry of Education) and R\&D Program of MOTIE/KEIT (10044909, Development of the long-lasting and broad-spectrum plant protectants).

\section{References}

Annonymous 2014. Rice market monitor. In: Monthly Report, Food and Agriculture Organization of the United Nations, vol. 17, iss. 1, pp 1-4.

Ahn, I. P., Lee, S. W. and Suh, S. C. 2007. Rhizobacteria induced priming in Arabidopsis is dependent on ethylene, jasmonic acid, and NPR1. Mol. Plant-Microbe Interact. 20:759-768.

Ahn, I. P., Kim, S., Kang, S., Suh, S. C. and Lee, Y. H. 2005. Rice defense mechanisms against Cochliobolus miyabeanus and Magnaporthe grisea are distinct. Phytopathology 95:1248-1255.

Ausubel, F. W., Brent, R., Kingston, R. E., Moore, D. D., Seidman, J. G., Smith, J. A. and Struhl, K. 1995. Current Protocols in Molecular Biology, New York: Wiley.

Bibi, F., Yasir, M., Song, G. C., Lee, S. Y. and Chung, Y. R. 2012. Diversity and characterization of endophytic bacteria associated with tidal flat plants and their antagonistic effects on oomycetous plant pathogens. Plant Pathol. J. 28:20-31.

Bibi, F., Chung, E. J., Jeon, C. O. and Chung, Y. R. 2011. Bacillus graminis sp. nov., an endophytic bacterium isolated from a coastal dune plant. Int. J. Syst. Evol. Microbiol. 61:1567-1571.

Bais, H. P., Fall, R. and Vivanco, J. M. 2004. Biocontrol of Bacillus subtilis against infection of Arabidopsis roots by Pseudomonas syringae is facilitated by biofilm formation and surfactin production. Plant Physiol. 134:307-319.

Bonman, J. M. 1992. Root and crown disease, bakanae. In: Compendium of Rice Diseases, eds. by R. K. Webster and P. S. Gunnell, p. 27. APS press, University of California, Davis.

Bouizgarne, B. 2013. Bacteria for plant growth promotion and disease management. In: Bacteria in Agrobiology, Disease Mangement, ed. by D. K. Maheshwari, pp. 15-34. SpringerVerlag, Berlin, Heidelberg.

Chen, X. H., Scholz, R., Borriss, M., Junge, H., Mogel, G., Kunz, S. and Borriss, R. 2009. Difficidin and bacilysin produced by plant associated Bacillus amyloliquefaciens are efficient in controlling fire blight disease. J. Biotechnol. 140:38-44.

Choi, G. J., Kim, J. C., Park, E. J., Choi, Y. H., Jang, K. S., Lim, H. K., Cho, K. Y. and Lee, S. W. 2006. Biological control activity of two isolates of Pseudomonas fluorescens against rice sheath blight. Plant Pathol. J. 22:289-294.

Cottyn, B., Cerez, M. T., Van Outryve, M. F., Barroga, J., Swings, J. and Mew, T. W. 1996. Bacterial diseases of rice. I. Pathogenic bacteria associated with sheath rot complex and grain discoloration of rice in the Philippines. Plant Dis. 80:429-437. 
Crane, J. M., Gibson, D. M., Vaughan, R. H. and Bergstrom, G. C. 2013. Iturin levels on wheat spikes linked to biological control of Fusarium head blight by Bacillus amyloliquefaciens. Phytopathology 103:146-155.

Croplife 2015. Bacterial panicle blight, the disease with the greatest impact on rice crops. (http://www.croplifela.org/en/ disease-of-the-month.html?id=182).

De Vleesschauwer, D., Van Buyten, E., Satoh, K., Balidion, J., Mauleon, R., Choi, I. R., Vera Cruz, C., Kikuchi, S. and Höfte, M. 2012. Brassinosteroids antagonize gibberellin and salicylate mediated root immunity in rice. Plant Physiol. 158:1833-1846.

Dimkic, I., Zivkovic, S., Beric, T., Ivanovic, Z., Gavrilovic, V., Stankovic, S. and Fira, D. 2013. Characterization and evaluation of two Bacillus strains, SS-12.6 and SS-13.1, as potential agents for the control of phytopathogenic bacteria and fungi. Biol. Control 65:312-321.

Dittmer, J. C. and Lester, R. L. 1964. A simple, specific spray for the detection of phospholipids on thin-layer chromatograms. $J$. Lipid Res. 15:126-127.

Felsenstein, J. 1985. Confidence limits on phylogenies: an approach using the bootstrap. Evolution 39:783-791.

Fitch, W. M. 1972. Toward defining the course of evolution: minimum change for a specific tree topology. Syst. Biol. 20:406-416.

Gnanamanickam, S. S. 2009. An overview of progress in biological control. In: Biological Control of Rice Diseases, Progress in Biological Control, ed. by S. S. Gnanamanickam, vol. 8, pp. 43-51. Springer, Netherlands.

Goris, J., Konstantinidis, K. T., Klappenbach, J. A., Coenye, T., Vandamme, P. and Tiedje, J. M. 2007. DNA-DNA hybridization values and their relationship to whole genome sequence similarities. Int. J. Syst. Evol. Microbiol. 57:81-91.

Hall, T. A. 1999. BioEdit: a user friendly biological sequence aligned editor and analysis program for Windows 95/98/NT. Nucleic Acids Symp. Ser. 41:95-98.

Hu, X., Roberts, D. P., Maul, J. E., Emche, S. E., Liao, X., Guo, X., Liu, Y., McKenna, L. F., Buyer, J. S. and Liu, S. 2011. Formulations of the endophytic bacterium Bacillus subtilis Tu-100 suppress Sclerotinia sclerotiorum on oilseed rape and improve plant vigor in field trials conducted at separate locations. Can. J. Microbiol. 57:539-546.

Jacin, H. and Mishkin, A. R. 1965. Separation of carbohydrates on borate impregnated silica gel G plates. J. Chromatogr. 18:170-173.

Kämpfer, P. 1994. Limits and possibilities of total fatty acid analysis for classification and identification of Bacillus species. Syst. Appl. Microbiol. 17:86-98.

Kang, H., Weerawongwiwat, V., Kim, J. H., Sukhoom, A. and Kim, W. 2013. Bacillus songkensis sp. nov., isolated from soil. Int. J. Syst. Evol. Microbiol. 63:4189-4195.

Kazempour, M. N. and Elahinia, S. A. 2007. Biological control of Fusarium fujikuroi, the causal agent of bakanae disease by rice associated antagonistic bacteria. Bulg. J. Agric. Sci.
13:393-408.

Kim, O. S., Cho, Y. J., Lee, K., Yoon, S. H., Kim, M., Na, H., Park, S. C., Jeon, Y. S., Lee, J. H., Yi, H., Won, S. and Chun, J. 2012. Introducing EzTaxon-e: a prokaryotic 16S rRNA gene sequence database with phylotypes that represent uncultured species. Int. J. Syst. Evol. Microbiol. 62:716-721.

Kim, J., Kang, Y., Kim, J. G., Choi, O. and Hwang, I. 2010. Occurrence of Burkholderia glumae on rice and field crops in Korea. Plant Pathol. J. 26:271-272.

Kloepper, J. W., Ryu, C. M. and Zhang, S. 2004. Induced systemic resistance and promotion of plant growth by Bacillus spp. Phytopathology 94:1259-1266.

Komagata, K. and Suzuki, K. 1987. Lipid and cell-wall analysis in bacterial systematics. Methods Microbiol. 19:161-207.

Lane, D. J. 1991. 16S/23S rRNA sequencing. In: Nucleic Acid Techniques in Bacterial Systematics, eds. by E. Stackebrandt and M. Goodfellow, pp. 115-175. Chichester: Wiley.

Lee, S. H., Shim, J. K., Kim, J. M., Choi, H. K. and Jeon, C. O. 2011. Henriciella litoralis sp. nov., isolated from a tidal flat, transfer of Maribaculam marinum Lai et al. to the genus Henriciella as Henriciella aquimarina nom. nov. and emended description of genus Henriciella. Int. J. Syst. Evol. Microbiol. 61:722-727.

LPSN. 2015. List of prokaryotic names with standing in nomenclature. (http://www.bacterio.net/bacillus.html).

Madhaiyan, M., Poonguzhali, S., Kwon, S. W. and Sa, T. M. 2010. Bacillus methylotrophicus sp. nov., a methanol utilizing, plant growth promoting bacterium isolated from rice rhizosphere soil. Int. J. Syst. Evol. Microbiol. 60:2490-2495.

McSpadden Gardener, B. 2010. Biocontrol of plant pathogens and plant growth promotion by Bacillus. In: Recent Developments in Management of Plant Diseases, Plant Pathology in the 21st Century. eds. by U. Gisi, I. Chet and M. L. Gullino, chapt. 6, pp. 71-79. Springer-Amsterdam.

Mesbah, M., Premachandran, U. and Whitman, W. B. 1989. Precise measurement of the $\mathrm{G}+\mathrm{C}$ content of deoxyribonucleic acid by high-performance liquid chromatography. Int. J. Syst. Bacteriol. 39:159-167.

Mew, T. W. 1992. Foliar disease, bacterial blight. In: Compendium of Rice Diseases, eds. by R. K. Webster and P. S. Gunnell, pp. 10-11. APS press, University of California, Davis.

Minnikin, D. E., O’Donnell, A. G., Goodfellow, M., Alderson, G., Athalye, M., Schaal, A. and Parlett, J. H. 1984. An integrated procedure for the extraction of bacterial isoprenoid quinones and polar lipids. J. Microbiol. Methods 2:233-241.

Misra, J. K., Mew, T. W. and Merca, S. D. 1994. Field inspection. In: A Manual of Rice Seed Health Testing, eds. by T. W. Mew and J. K. Misra, pp. 52-55. International Rice Research Institute, Philippines.

Niu, D. D., Liu, H. X., Jiang, C. H., Wang, Y. P., Wang, Q. Y., Jin, H. L. and Guo, J. H. 2011. The plant growth promoting rhizobacterium Bacillus cereus AR156 induces systemic resistance in Arabidopsis thaliana by simultaneously activating salicylate-and jasmonate/ethylene dependent signaling pathways. 
Mol. Plant-Microbe Interact. 24:533-542.

Ou, S. H. 1985. Rice disease. 2nd ed. Commonwealth Mycol. Inst., Key, England. 361 pp.

Park, K. S., Paul, D., Kim, J. S. and Park, J. W. 2009. L-alanine augments Rhizobacteria induced systemic resistance in cucumber. Folia Microbiol. 54:322-326.

Park, K. S., Paul, D. and Yeh, W. H. 2006. Bacillus vallismortis EXTN-1 mediated growth promotion and disease suppression in rice. Plant Pathol. J. 22:278-282.

Parte, A. C. 2014. LPSN-list of prokaryotic names with standing in nomenclature. Nucleic Acids Res. 42:613-616.

Picard, C., Baruffa, E. and Bosco, M. 2008. Enrichment and diversity of plant probiotic microorganisms in the rhizosphere of hybrid maize during four growth cycles. Soil Biol. Biochem. 40:106-115.

Reichenbach, H. 1992. The order Cytophagales. In: The Prokaryotes, eds. by A. Balows, H. G. Trüper, M. Dworkin, W. Harder and K. H. Schleifer, 2nd ed., vol. 4, pp. 3631-3675. Springer, New York.

Rosales, A. M. and Mew, T. W. 1997. Suppression of Fusarium moniliforme in rice by rice-associated antagonistic bacteria. Plant Dis. 81:49-52.

Ross, H. N. M., Grant, W. D. and Harris, J. E. 1985. Lipids in archaebacterial taxonomy. In: Chemical Methods in Bacterial Systematics, eds. by M. Goodfellow and D. E. Minnikin, pp. 289-300. Academic Press, London.

Ryu, C. M. 2013. Promoting plant protection by root-associated microbes. Plant Pathol. J. 29:123-124.

Ryu, C. M., Farag, M. A., Hu, C. H., Reddy, M. S., Kloepper, J. W. and Pare, P. W. 2004. Bacterial volatiles induce systemic resistance in Arabidopsis. Plant Physiol. 134:1017-1026.

Ryu, C. M., Murphy, J. F., Mysore, K. S. and Kloepper, J. W. 2004. Plant growth promoting rhizobacteria systemically protect Arabidopsis thaliana against cucumber mosaic virus by a salicylic acid and NPR1 independent and jasmonic acid dependent signaling pathway. Plant J. 38:381-392.

Saitou, N. and Nei, M. 1987. The neighbor-joining method: a new method for reconstructing phylogenetic trees. Mol. Biol. Evol. 4:406-425.

Savary, S., Willocquet, L., Elazegui, F. A., Castilla, N. P. and Teng, P. S. 2000. Rice pest constrainsts in tropical Asia: Quantification of yield losses due to rice pests in a range of production situations. Plant Dis. 84:357-369.

Schleifer, K. H. 1985. Analysis of the chemical composition and primary structure of murein. Methods Microbiol. 18:123-156.

Smibert, R. M. and Krieg, N. R. 1994. Phenotypic characterization. In: Methods for General and Molecular Bacteriology, eds. by P. Gerhardt, R. G. E. Murray, W. A. Wood and N. R. Krieg, pp. 607-654. American Society for Microbiology, Washington, DC.

Stackebrandt, E. and Goebel, B. M. 1994. Taxonomic Note: A place for DNA-DNA reassociation and 16s rRNA sequence analysis in the present species definition in bacteriology. Int. J. Syst. Bacteriol. 44:846-849.

Stanek, J. L. and Roberts, G. D. 1974. Simplified approach to identification of aerobic actinomycetes by thin-layer chromatography. Appl. Microbiol. 28:226-231.

Sumpavapol, P., Tongyonk, L., Tanasupawat, S., Chokesajjaatee, N., Luxananil, P. and Visessanguan, W. 2010. Bacillus siamensis sp. nov., isolated from salted crab (poo-khem) in Thailand. Int. J. Syst. Evol. Microbiol. 60:2364-2370.

Sung, K. C. and Chung, Y. R. 1997. Enhanced suppression of rice sheath blight using combination of bacteria which produce chitinases or antibiotics. In: Proceedings of the 4th International Workshop on Plant Growth Promoting Rhizobacteria Present Status and Future Prospects, eds. by A. Ogoshi, K. Kobayashi, Y. Homma, F. Kodama, N. Konodo and S. Akino, pp. 370-373. OECD, Paris.

Tamura, K., Peterson, D., Peterson, N., Stecher, G., Nei, M. and Kumar, S. 2011. MEGA5: molecular evolutionary genetics analysis using maximum likelihood, evolutionary distance, and maximum parsimony methods. Mol. Biol. Evol. 28:27312739.

Thompson, J. D., Gibson, T. J., Plewniak, F., Jeanmougin, F. and Higgins, D. G. 1997. The CLUSTAL_X windows interface: flexible strategies for multiple sequence alignment aided by quality analysis tools. Nucleic Acids Res. 25:4876-4882.

Ura, H., Furuya, N., Iiyama, K., Hidaka, M., Tsuchiya, K. and Matsuyama, N. 2006. Burkholderia gladioli associated with symptoms of bacterial grain rot and leaf-sheath browning of rice plants. J. Gen. Plant Pathol. 72:98-103.

Wang, D, Mukhtar, K. P., Culler, A. H. and Dong, X. 2007. Salicylic acid inhibits pathogen growth in plants through repression of the auxin signaling pathway. Curr. Biol. 17:17841790.

Xu, P., Li, W. J., Tang, S. K., Zhang, Y. Q., Chen, G. Z., Chen, H. H., Xu, L. H. and Jiang, C. 2005. Naxibacter alkalitolerans gen. nov., sp. nov., a novel member of the family 'Oxalobacteraceae' isolated from China. Int. J. Syst. Evol. Microbiol. 55:1149-1153.

Yang, Y. R., Kim, Y. C., Lee, S. W., Lee, S. W., An, G. G. and Kim, I. S. 2012. Involvement of an efflux transporter in prochloraz resistance of Fusarium fujikuroi CF245 causing rice bakanae disease. J. Korean Soc. Appl. Biol. Chem. 55:571-574.

Yang, J. W., Yu, S. H. and Ryu, C. M. 2009. Priming of defenserelated genes confers root-colonizing Bacilli-elicited induced systemic resistance in pepper. Plant Pathol. J. 25:389-399.

Yasir, M., Aslam, Z., Song, G. C., Jeon, C. O. and Chung, Y. R. 2010. Sphingosinicella vermicomposti sp. nov., isolated from vermicompost, and emended description of the genus Sphingosinicella. Int. J. Syst. Evol. Microbiol. 60:580-584. 